\title{
A rare combination of MODY5 and duodenal atresia in a patient: a case report
}

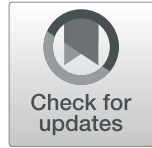

Tao Du* ${ }^{*}$, Nan Zeng, Xiaofang Wen, Peizhuang Zhu and Wangen Li*

\begin{abstract}
Background: Maturity-onset diabetes of the young (MODY) is a genetically and clinically heterogeneous group of hereditary diabetes, generally caused by one abnormal gene. MODY5 is caused by mutations of the hepatocyte nuclear factor 1 homeobox $\beta$ gene (HNF1 $\beta$ ), always as a part of Chr17q12 deletion, whereas heterozygous mutation in $B$ lymphocyte kinase (BLK) gene is responsible for MODY11.

Case presentation: We report a patient who developed diabetes with a 1.58-Mb Chr17q12 microdeletion and BLK gene c.211G > A mutation using the cytoscan high-density array and whole-exome sequencing analysis. The patient received the surgery at five days after birth for the duodenal atresia and had normal growth postoperatively. Mild elevated liver enzymes were found along with the normal renal function. Quantitative analysis of $\beta$-cell function markers, including fasting insulin $(<0.2 \mathrm{mlU} / \mathrm{L})$, fasting $C$-peptide $(0.02 \mu \mathrm{g} / \mathrm{L})$, postprandial-2 $\mathrm{h}$ insulin $(<0.2 \mathrm{mIU} / \mathrm{L})$, and postprandial-2 $\mathrm{h}$ C-peptide $(0.03 \mu \mathrm{g} / \mathrm{L})$ suggested a severe loss of insulin secreting capacity. Meanwhile, islet autoantibodies (GADA, IA-2, ICA, and IAA) in the patient's blood appeared negative. Neither dysplasia in other tissues nor abnormality in development and behavior was found.
\end{abstract}

Conclusion: To date, gastrointestinal malformations were extremely rarely reported in patients with MODY. Our clinical report further expands the clinical presentation and variability of MODY5.

Keywords: 17q12 microdeletion, Duodenal atresia, Hepatocyte nuclear factor beta, B lymphocyte kinase

\section{Background}

Maturity-onset diabetes of the young (MODY) is a monogenic form of non-autoimmune diabetes mellitus that usually first presents in adolescence or young adulthood, accounting for up to $2 \%$ of diabetes in people ages 20 and younger in the United States [1]. Depending on the clinical and genetic heterogeneity, 14 subtypes of genetic defects have been proposed to cause MODY [2]. For example, mutation in hepatocyte nuclear transcription factor 1 homeobox $\beta$ (HNF1 $\beta$ ) causes MODY5, which accounts for 2 to $6 \%$ of MODY [3]. On the other hand, approximately $50 \%$ of patients with MODY 5 are diagnosed with a whole HNF1 $\beta$ gene deletion, which is virtually always part of a Chr17q12 deletion syndrome. Chr17q12 deletion syndrome usually comprises MODY5, and other diseases (i.e., cystic renal disease, pancreatic atrophy, female genital tract abnormalities, and variable cognitive involvement) $[4,5]$. MODY11 is caused by Ala71Thr

\footnotetext{
* Correspondence: dutao@gzhmu.edu.cn; liwg660@126.com Department of Endocrinology, The Second Affiliated Hospital of Guangzhou Medical University, Guangzhou 510260, People's Republic of China
}

mutation in the B lymphocyte kinase (BLK) gene with attenuated BLK activity [6]. BLK is expressed in $\beta$-cells and enhances insulin synthesis and secretion in response to glucose.

Up to now, there is only one case with duodenal atresia reported to be associated with a $17 \mathrm{q} 12$ microdeletion [7]. Here, we report a MODY patient, with Chr17q12 microdeletion and BLK gene c.211G > A mutation, who had surgery at 5 days after birth for the duodenal atresia. The patient presented bilateral renal cyst without other illnesses or health problems.

\section{Case presentation}

The patient was born after a healthy gestation in the Guangdong Province of China and received surgery at 5 days after birth for intestine obstruction caused by the duodenal atresia. The patient's parents were nonconsanguineous and healthy without a family history of genetic disorders, congenital malformations, diabetes, and psychiatric disease. The patient was diagnosed with diabetes in a medical checkup at the age of 27 years in 2011.

(c) The Author(s). 2020 Open Access This article is distributed under the terms of the Creative Commons Attribution 4.0 International License (http://creativecommons.org/licenses/by/4.0/), which permits unrestricted use, distribution, and reproduction in any medium, provided you give appropriate credit to the original author(s) and the source, provide a link to the Creative Commons license, and indicate if changes were made. The Creative Commons Public Domain Dedication waiver (http://creativecommons.org/publicdomain/zero/1.0/) applies to the data made available in this article, unless otherwise stated. 
Since then, the patient has been receiving insulin treatment and had two pregnancies. During her first pregnancy in 2015, the patient was found with the fetal renal dysplasia and 17q12 deletion $(34,822,465-36,283,612)$ through by B-mode ultrasound and umbilical cord blood gene test, resulting in an induced abortion. Consequently, the patient carried a successful pregnancy and had a healthy daughter in 2017.

In March 2018, the patient was re-hospitalized due to poor glycemic control and hyperketonemia. Anthropometric measurements showed the patient had a body weight of $52 \mathrm{~kg}$ (average body weight of a Chinese female is $57.3 \mathrm{~kg}$ ), a height of $162 \mathrm{~cm}$ (average height of a Chinese female is $155.8 \mathrm{~cm}$ ), and a body mass index (BMI) of $19.81 \mathrm{~kg} / \mathrm{m}^{2}$ (normal rang $18.5-23.9 \mathrm{~kg} / \mathrm{m}^{2}$ ). Other physical examination results were likewise unremarkable. Mild elevated liver enzymes were discovered (aspartate aminotransferase $47 \mathrm{IU} /$ $\mathrm{L}$, alanine aminotransferase $52 \mathrm{IU} / \mathrm{L}$, lactose dehydrogenase $518 \mathrm{IU} / \mathrm{L}$, alkaline phosphatase $152 \mathrm{IU} / \mathrm{L}$ and $\gamma$-glutamyl transferase $54 \mathrm{IU} / \mathrm{L})$, while renal function was normal (blood urea nitrogen $6.07 \mathrm{mmol} / \mathrm{L}$, creatinine $61.1 \mu \mathrm{mol} / \mathrm{L}$, negative for urinary protein). Plasma glucose was 16.74 $\mathrm{mmol} / \mathrm{L}, \mathrm{HbA} 1 \mathrm{c}$ was $12.2 \%$, and blood ketone was 2.8 $\mathrm{mmol} / \mathrm{L}$. Analysis of $\beta$-cell function markers, including fasting insulin $(<0.2 \mathrm{mIU} / \mathrm{L})$, fasting C-peptide $(0.02 \mu \mathrm{g} / \mathrm{L})$, postprandial- $2 \mathrm{~h}$ insulin $(<0.2 \mathrm{mIU} / \mathrm{L})$, and postprandial-2 h C-peptide $(0.03 \mu \mathrm{g} / \mathrm{L})$ suggested a severe loss of insulin secreting capacity (electrochemiluminescence immunoassay was used for insulin and C-peptide concentration). The patient was treated with insulin aspart in continuous insulin infusion (20/U insulin for basal/pre-meal bolus doses). Lab examination results showed negative anti-islet autoantibodies (GADA, IA-2, ICA, and IAA) in the patient's blood using ELISA (GADA), radiobinding assay (IA-2), and radioimmunoassay (ICA and IAA), respectively. Echocardiography and plain X-rays analysis showed normal results. B-mode ultrasound showed a bilateral renal cyst, and cardiac color doppler ultrasound displayed a slightly tricuspid regurgitation.

To pinpoint the causative mutations in the patient, we used the cytoscan high-density array to identify microduplications or microdeletions, and used wholeexome sequencing to detect the mutations in genes. In brief, the cytoscan $750 \mathrm{~K}$ Array (Affymetrix Inc., Santa

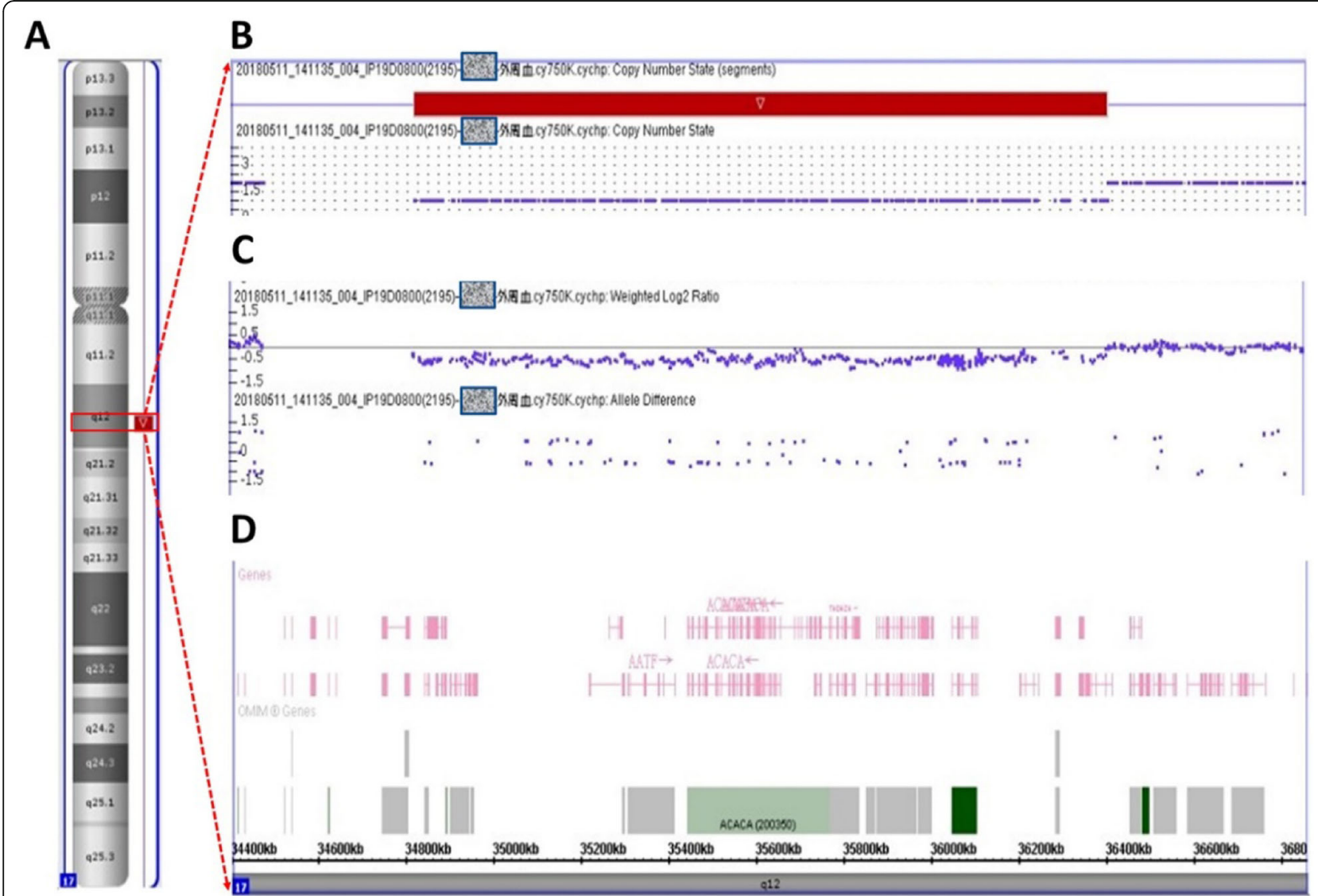

Fig. 1 Molecular karyotyping revealed a deletion of approximately 1.58-Mb in Chr17q12 in patients. a Chromosome ideogram. The deletion region is highlighted in red. b Cytoscan high-density array identified a 1.58-Mb region $(34,822,465-36,404,104)$ of hemizygous loss. c Magnification of the hemizygous loss region. $\mathbf{d}$ Genes located in the 1.58-Mb hemizygous loss region 
Clara, CA) was used for chromosomal microarray, containing 550,000 nonpolymorphic probes and 200,436 single nucleotide polymorphic probes. The copy number variation was analyzed using the Affymetrix Chromosome Analysis Suite software (Version 3.0) and interpreted with the aid of UCSC genome browser (http://gemome.ucsc.edu). The exon coding regions of ABCC8, AKT2, BLK, CEL, EIF2AK3, GCK, GLIS3, GLUD1, HADH, HNF1A, HNF1B, HNF4A, INS, INSR, KCNJ11, KLF11, MAPK8IP1, NEUROD1, PAX4, PDX1, PLAGL1, PTF1A, RFX6, SLC19A2, SLC2A2, UCP2, and ZFP57 were directly sequenced to discover possible gene mutations. The analysis results showed a $1.58-\mathrm{Mb}$ region $(34,822,465-36,404,104)$ of hemizygous loss in Chr17q12 (Fig. 1) and BLK gene p.Ala71Thr (c.211G > A) mutation. The patient showed diabetes and renal cysts. Nevertheless, no other illnesses or health problems were found. To elucidate the various clinical presentations and characteristics of Chr17 deletion, we compared the clinical manifestations in our proband and previously reported patients with a similar deletion region $(34,437.475-36,424,950)$ in Chr17q12 [7-15] (Fig. 2, Table 1). As shown in Table 1, individuals with similar gene deletions could manifest various presentations and disorders (such as diabetes, renal cysts, liver and pancreas malformations, and intellectual disability). Even between parents and children without differences in the deletion region, the significant variance in clinical phenotypes is presented $[7,11,13]$. Likewise, the severity of renal and pancreatic defects varied between monozygotic twins with MODY5 due to Chr17q12 deletion [8].

\section{Discussion and conclusions}

It has been reported that the incidence of MODY5 is up to $50 \%$ [16] or $82 \%$ in Chr17q12 deletion [17]. The renal cystic dysplasia and other structural renal anomalies are the most commonly reported manifestation of the Chr17q12 deletion [16, 17]. The whole gene deletion and mutations in the coding region or splice sites of HNF1B cause MODY5 (2 to 6\% of MODY diagnoses) that is typically characterized by additional HNF1Brelated kidney disease, pancreatic hypoplasia, genital tract malformations, abnormal liver function and earlyonset gout [3]. It is known that the minimum size for the Chr17q12 deletion is $1.4 \mathrm{Mb}$ DNA sequence in the approximate position of chr17: 34,815,072 - 36,192,492 [16]. Our patient's deletion is $1.58-\mathrm{Mb}$ DNA sequence at the position of chr17: 34,822,465-36,404,104. Notably, our patient diagnosed as MODY5 with bilateral renal cysts has no other severe abnormal phenotypes, while some patients with similar deletion region of chr17 were reported to have the short stature, speech delay and dyspraxia, psychopathology, or autistic traits (Table 1). Among previously studies, three studies reported the gastroesophageal reflux disease in individuals with chr17q12 deletion $[13,14,18]$, and only one reported the duodenal atresia in the individual with chr17q12

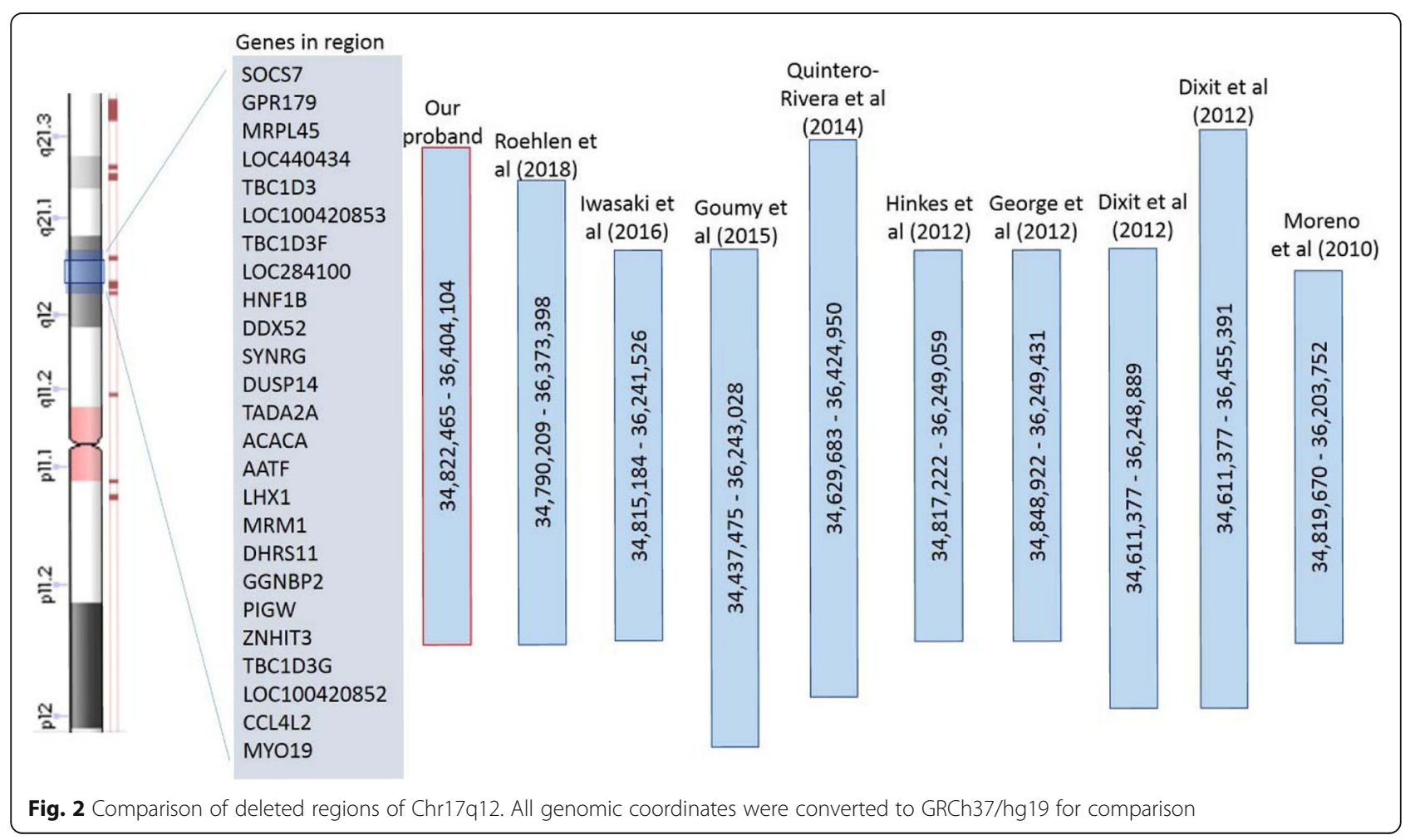


Table 1 Comparisons of clinical manifestations in our proband and previously reported patients with a similar phenotype or deletion region in Chr17q12

\begin{tabular}{|c|c|c|c|c|c|c|c|c|c|}
\hline & $\begin{array}{l}\text { Our } \\
\text { proband }\end{array}$ & $\begin{array}{l}\text { Roehlen } \\
\text { et al. (2018) } \\
\text { [15] }\end{array}$ & $\begin{array}{l}\text { Iwasaki } \\
\text { et al. (2016) } \\
\text { [9] }\end{array}$ & $\begin{array}{l}\text { Goumy } \\
\text { et al. (2015) } \\
\text { [14] }\end{array}$ & $\begin{array}{l}\text { Quintero-Rivera } \\
\text { et al. (2014) [7] }\end{array}$ & $\begin{array}{l}\text { Hinkes et al. } \\
\text { (2012) [12] }\end{array}$ & $\begin{array}{l}\text { George } \\
\text { et al. (2012) } \\
\text { [11] }\end{array}$ & $\begin{array}{l}\text { Dixit et al. } \\
\text { (2012) [10] }\end{array}$ & $\begin{array}{l}\text { Moreno-De-Luca } \\
\text { et al. (2010) [13] }\end{array}$ \\
\hline $\begin{array}{l}\text { Diabetes } \\
\text { mellitus }\end{array}$ & + & $2 / 2$ & + & NR & - & + & $0 / 2$ & $0 / 3$ & $1 / 9$ \\
\hline Renal cysts & + & $2 / 2$ & + & + & + & + & $1 / 2$ & $3 / 3$ & + \\
\hline $\begin{array}{l}\text { Pancreas } \\
\text { abnormalities }\end{array}$ & - & $2 / 2$ & + & NR & - & NR & NR & $0 / 3$ & NR \\
\hline $\begin{array}{l}\text { Liver } \\
\text { abnormalities }\end{array}$ & + & $2 / 2$ & + & + & + & NR & NR & $1 / 3$ & NR \\
\hline $\begin{array}{l}\text { Facial } \\
\text { dysmorphism }\end{array}$ & - & $1 / 2$ & NR & + & + & NR & NR & $2 / 3$ & $9 / 9$ \\
\hline Joint laxity & - & NR & NR & NR & + & + & NR & $0 / 3$ & NR \\
\hline $\begin{array}{l}\text { Short stature or } \\
\text { failure to thrive }\end{array}$ & - & NR & NR & - & - & NR & $0 / 2$ & $1 / 3$ & $1 / 9$ \\
\hline $\begin{array}{l}\text { Autism } \\
\text { spectrum } \\
\text { disorder }\end{array}$ & - & NR & NR & - & NR & - & $0 / 2$ & $1 / 3$ & $6 / 9$ \\
\hline $\begin{array}{l}\text { Intellectual } \\
\text { impairment }\end{array}$ & - & $2 / 2$ & NR & - & NR & - & $2 / 2$ & $3 / 3$ & $8 / 9$ \\
\hline Aggression & - & NR & NR & & NR & - & NR & NR & $2 / 9$ \\
\hline $\begin{array}{l}\text { Anxiety/ } \\
\text { disruptive } \\
\text { behavior }\end{array}$ & - & NR & NR & - & NR & - & $1 / 2$ & NR & $5 / 9$ \\
\hline Hyperactivity & - & $N R$ & NR & NR & - & - & $1 / 2$ & NR & $2 / 9$ \\
\hline $\begin{array}{l}\text { Gastrointestinal } \\
\text { abnormalities }\end{array}$ & $\mathrm{DA}$ & NR & NR & GERD & $\mathrm{DA}$ & NR & NR & NR & $\begin{array}{l}\text { GERD }(2 / 9), F C \\
(2 / 9)\end{array}$ \\
\hline
\end{tabular}

+: feature is present, -: feature is absent, NR Not reported, DA Duodenal atresia, GERD Gastroesophageal reflux disease, FC Frequent constipation

deletion [7]. Interestingly, duodenal atresia has been reported in one patient with 17q12 duplication [18]. Therefore, it is strongly suggested that genetic defects alone are not sufficient to result in the clinical features associated with the Chr17q12 deletion.

In our patient, BLK Ala71Thr mutation was detected. In 2004, Kim et al. firstly reported the MODY was associated with Chr8p23 [19]. Borowiec et al. showed the BLK Ala71Thr mutation was responsible for MODY11 by resequencing genomic sequence at 8p23 in 6 MODY families, and revealed the mutation altered the BLK expression and affected MIN6 B-cells activity [6]. However, Bonnefond et al. demonstrated a nominal association between this variant and increased type 2 diabetes risk and no mutation in BLK in 64 unelucidated MODY samples [20]. The genome databases also show the frequency of BLK p.Ala71Thr (c.211G > A) mutation is very low, only 0.01193 from the Genome Aggregation Database (gnomAD), 0.01171 from Exome Aggregation Consortium (ExAC), and 0.01238 from Global Minor Allele Frequency (GMAF). It suggests that the BLK variant is a benign or a pathological factor combined with other diabetic risk factors. In our case, the patient had a severe loss of insulin secretion capacity with BLK mutation and Chr17q12 deletion, but it was still difficult to evaluate the effect of BLK mutation on diabetes. According to the previously reported data, the BLK variant as a pathology of MODY still requires further validation.

The previous studies revealed the various clinical manifestations of Chr17q12 deletion. Here, we reported a woman who developed MODY5 with the Chr17q12 deletion and duodenal atresia. Our reported new phenomena further demonstrated the clinical variability of MODY5.

\section{Abbreviations}

ABCC8: Adenosine triphosphate (ATP)-binding cassette; sub-family C (CFTR/ MRP) member 8; AKT2: Protein kinase B beta; BLK: Heterozygous mutation in B lymphocyte kinase; BMI: Body mass index; CEL: Carboxyl ester lipase; EIF2AK3: Eukaryotic translation initiation factor 2-alpha kinase 3;

ELISA: Enzyme-linked immunosorbent assay; ExAC: Exome Aggregation Consortium; GADA: Glutamic acid decarboxylase 65 autoantibody; GCK: Glucokinase (GCK); GLIS3: GLI-similar 3; GLUD1: Glutamate dehydrogenase 1 gene; GMAF: Global Minor Allele Frequency; gnomAD: Genome Aggregation Database; HADH: Hydroxy-acyl-CoA dehydrogenase; HNF1A: Hepatocyte nuclear factor 1A; HNF1B: Hepatocyte nuclear factor 1B; HNF1 $\beta$ : Hepatocyte nuclear factor 1 homeobox $\beta$ gene; HNF4A: Hepatocyte nuclear factor 4A; IA2A: Insulinoma-associated protein 2 autoantibody; IAA: Insulin autoantibody; ICA: Islet cell autoantibodies; INS: Insulin; INSR: Insulin receptor; KCNJ11: Potassium channel inwardly rectifying subfamily; member 11; KLF11: Kruppel-like factor 11; MAPK8IP1: Mitogen-activated protein kinase 8 interacting protein 1; MODY: Maturity-onset diabetes of the young; NEUROD1: Neurogenic differentiation 1; PAX4: Paired-box-containing gene 4; PDX1: Pancreatic and 
duodenal homeobox 1; PLAGL1: Pleiomorphic adenoma gene 1; PTF1A: Pancreas-specific transcription factor 1A; RFX6: Regulatory factor X 6; SLC19A2: Solute carrier family 19 member 2; SLC2A2: Solute carrier family 2 member 2; UCP2: Uncoupling Protein 2; ZFP57: Zinc finger protein 57

\section{Acknowledgments}

The authors sincerely thank the patient's collaboration.

\section{Authors' contributions}

TD and NZ collected the clinical information and the literature data, and drafted the manuscript. XW and PZ coordinated the gene evaluation and study. WL critically reviewed and edited the manuscript. All authors approved the submitted version of the manuscript.

\section{Funding}

This work was supported by the Natural Science Foundation of Guangdong Province of China (No. 2014A030313488), the Science and Technology Planning Project of Guangzhou City of China (No. 201607010036), the Science and Technology Planning Project of Guangdong Province of China (No. 2016A030303066). These funds sponsored the genetic test and analysis, and the other expense we conducted for this case. The funding bodies played no role in the design of the study and collection, analysis, and interpretation of data and in writing the manuscript.

\section{Availability of data and materials}

The data used and/or analyzed in the present report were deposited in the Sequence Read Archive (SRA) database. The data are accessible via the SRA accession: PRJNA600784; or via the links: https://www.ncbi.nlm.nih.gov/sra/ PRJNA600784; https://trace.ncbi.nlm.nih.gov/Traces/sra/?run=SRR10875069.

\section{Ethics approval and consent to participate}

This study was approved by the academic ethics review boards of the Second Affiliated Hospital of Guangzhou Medical University. The authors obtained written consent from the patient for all genetic analysis.

\section{Consent for publication}

All authors declared the patient has signed written informed consent for publication of clinical, radiological, and biological data.

\section{Competing interests}

The authors declare that they have no competing interests.

Received: 4 July 2019 Accepted: 15 January 2020

Published online: 06 February 2020

\section{References}

1. Pihoker C, Gilliam LK, Ellard S, Dabelea D, Davis C, Dolan LM, Greenbaum CJ, Imperatore G, Lawrence JM, Marcovina SM, et al. Prevalence, characteristics and clinical diagnosis of maturity onset diabetes of the young due to mutations in HNF1A, HNF4A, and glucokinase: results from the SEARCH for diabetes in youth. J Clin Endocrinol Metab. 2013;98(10):4055-62.

2. Kim SH. Maturity-onset diabetes of the young: what do clinicians need to know? Diabetes Metab J. 2015;39(6):468-77.

3. Clissold RL, Hamilton AJ, Hattersley AT, Ellard S, Bingham C. HNF1Bassociated renal and extra-renal disease-an expanding clinical spectrum. Nat Rev Nephrol. 2015;11(2):102-12.

4. Loirat C, Bellanne-Chantelot C, Husson I, Deschenes G, Guigonis V, Chabane N. Autism in three patients with cystic or hyperechogenic kidneys and chromosome 17q12 deletion. Nephrol Dial Transplant. 2010;25(10):3430-3.

5. Nagamani SC, Erez A, Shen J, Li C, Roeder E, Cox S, Karaviti L, Pearson M, Kang $\mathrm{SH}$, Sahoo T, et al. Clinical spectrum associated with recurrent genomic rearrangements in chromosome 17q12. Eur J Hum Genet. 2010; 18(3):278-84.

6. Borowiec M, Liew CW, Thompson R, Boonyasrisawat W, Hu J, Mlynarski WM, El Khattabi I, Kim SH, Marselli L, Rich SS, et al. Mutations at the BLK locus linked to maturity onset diabetes of the young and beta-cell dysfunction. Proc Natl Acad Sci U S A. 2009;106(34):14460-5.

7. Quintero-Rivera F, Woo JS, Bomberg EM, Wallace WD, Peredo J, Dipple KM. Duodenal atresia in 17q12 microdeletion including HNF1B: a new associated malformation in this syndrome. Am J Med Genet A. 2014; 164A(12):3076-82.
8. Ohara Y, Okada Y, Yamada T, Sugawara K, Kanatani M, Fukuoka H, Hirota Y, Maeda T, Morisada N, lijima K, et al. Phenotypic differences and similarities of monozygotic twins with maturity-onset diabetes of the young type 5. J Diabetes Investig. 2019;10(4):1112-5.

9. Iwasaki N, Tsurumi M, Asai K, Shimuzu W, Watanabe A, Ogata M, Takizawa M, Ide R, Yamamoto T, Saito K. Pancreatic developmental defect evaluated by celiac artery angiography in a patient with MODY5. Hum Genome Var. 2016;3:16022.

10. Dixit A, Patel C, Harrison R, Jarvis J, Hulton S, Smith N, Yates K, Silcock L, McMullan DJ, Suri M. 17q12 microdeletion syndrome: three patients illustrating the phenotypic spectrum. Am J Med Genet A. 2012;158A(9): 2317-21.

11. George AM, Love DR, Hayes I, Tsang B. Recurrent transmission of a 17q12 microdeletion and a variable clinical Spectrum. Mol Syndromol. 2012;2(2):72-5.

12. Hinkes B, Hilgers KF, Bolz HJ, Goppelt-Struebe M, Amann K, Nagl S, Bergmann C, Rascher W, Eckardt KU, Jacobi J. A complex microdeletion $17 q 12$ phenotype in a patient with recurrent de novo membranous nephropathy. BMC Nephrol. 2012;13:27.

13. Moreno-De-Luca D, Consortium S, Mulle JG, Simons Simplex Collection Genetics C, Kaminsky EB, Sanders SJ, GeneStar, Myers SM, Adam MP, Pakula AT, et al. Deletion $17 q 12$ is a recurrent copy number variant that confers high risk of autism and schizophrenia. Am J Hum Genet. 2010;87(5):618-30.

14. Goumy C, Laffargue F, Eymard-Pierre E, Kemeny S, Gay-Bellile M, Gouas L, Gallot D, Francannet C, Tchirkov A, Pebrel-Richard C, et al. Congenital diaphragmatic hernia may be associated with $17 q 12$ microdeletion syndrome. Am J Med Genet A. 2015;167A(1):250-3.

15. Roehlen N, Hilger H, Stock F, Gläser B, Guhl J, Schmitt-Graeff A, Seufert J, Laubner K. 17q12 Deletion Syndrome as a Rare Cause for Diabetes Mellitus Type MODY5. J Clin Endocrinol Metab. 2018;103(10):3601-10.

16. Mitchel MW, Moreno-De-Luca D, Myers SM, Finucane B, Ledbetter DH, Martin CL. 17q12 Recurrent Deletion Syndrome. In: Adam MP, Ardinger HH, Pagon RA, Wallace SE, Bean LJH, Stephens K, Amemiya A, editors. GeneReviews ${ }^{\circledast}$ [Internet]. Seattle (WA): University of Washington, Seattle; 1993-2019.

17. Dubois-Laforgue D, Cornu E, Saint-Martin C, Coste J, Bellanne-Chantelot C, Timsit J, Monogenic Diabetes Study Group of the Societe Francophone du D. Diabetes, associated clinical spectrum, long-term prognosis, and genotype/phenotype correlations in 201 adult patients with hepatocyte nuclear factor 1B (HNF1B) molecular defects. Diabetes Care. 2017:40(11): 1436-43.

18. Rasmussen M, Vestergaard EM, Graakjaer J, Petkov Y, Bache I, Fagerberg C, Kibaek M, Svaneby D, Petersen OB, Brasch-Andersen C, et al. 17q12 deletion and duplication syndrome in Denmark-A clinical cohort of 38 patients and review of the literature. Am J Med Genet A. 2016;170(11):2934-42.

19. Kim SH, Ma X, Weremowicz S, Ercolino T, Powers C, Mlynarski W, Bashan KA, Warram JH, Mychaleckyj J, Rich SS, et al. Identification of a locus for maturity-onset diabetes of the young on chromosome 8p23. Diabetes. 2004;53(5):1375-84.

20. Bonnefond A, Yengo L, Philippe J, Dechaume A, Ezzidi I, Vaillant E, Gjesing $A P$, Andersson EA, Czernichow S, Hercberg $S$, et al. Reassessment of the putative role of BLK-p.A71T loss-of-function mutation in MODY and type 2 diabetes. Diabetologia. 2013;56(3):492-6.

\section{Publisher's Note}

Springer Nature remains neutral with regard to jurisdictional claims in published maps and institutional affiliations.

Ready to submit your research? Choose BMC and benefit from:

- fast, convenient online submission

- thorough peer review by experienced researchers in your field

- rapid publication on acceptance

- support for research data, including large and complex data types

- gold Open Access which fosters wider collaboration and increased citations

- maximum visibility for your research: over $100 \mathrm{M}$ website views per year

At BMC, research is always in progress.

Learn more biomedcentral.com/submissions 